Jurassic-Recent level bottom taxa persist to the present.

In view of the above it is likely that following severe environmental stress capable of generating major extinction events preserved in the fossil record the reef community complex normally is eliminated in toto, but that elements, sometimes a large percentage, of the level bottom fauna and its communities persist. Supporting this conclusion is the fact that during the highly provincial Ordovician, Permian, and later Cretaceous, the biogeographically distinctive reef community complexes in different parts of the world terminate at the same time.

I suspect that other trophically complex community types such as pelmatozoan thickets, bryozoan thickets and sponge forests, behave in a fashion similar to the reef community complex rather than to the trophically simpler level bottom communities.

It seems clear that the geologicalpalaeontological evidence strongly supports Pimm ${ }^{1}, \mathrm{May}^{2}$, and the others in their conclusions based on a variety of non-geological evidence.

A. J. Boucot Departments of Geology and Zoology, Oregon State University,

Corvallis,

Oregon 97331, USA

1. Pimm, S.L. Nature, 307, 321-326 (1984).

2. May, R.M. Stability and Complexity in Model Ecosystems (Princeton University, Press, 1973).

3. Boucot, A. J. J. Puleo., 57, 1-30 (1983).

\section{Icosahedra in aluminium / manganese alloy}

SIR - The experimental observations of regions of icosahedral order in a splatcooled alloy of $\mathrm{Al} / \mathrm{Mn}^{1,2}$ have excited considerable comment on a novel type of structure which hitherto had been purely conjectural $^{3}$. One way of considering the proposed structure is as the packing of two kinds of rhombohedral units cells, both having the same cell side but one being acute with $\alpha=63.43^{\circ}$ and the other obtuse with $\alpha=116.57^{\circ}$. These arc repeated according to what has become known as the three-dimensional Penrose pattern, and in a ratio of $\tau$ acute units to each obtuse unit, where $\tau$ is the golden number 1.618 .. The pattern is intrinsically recursive or hierarchic. I wish to point out further similarities with structures already known. There arc at least three types of structures entailing local icosahedral symmetry which may be extended hierarchically for various ranges through the material, according to the balance of the demands of local and of long-range ordcring. These include:

(1) Close-packed metal structures where, as pointed out by Frank in $1952^{4}, 12$ spheres will pack icosahedrally around a thirteenth which has $95 \%$ of their diameter. This is well known in alloys, most clearly in the structure ${ }^{5}$ of $\mathrm{Mg}_{32}(\mathrm{Zn}, \mathrm{Al})_{49}$ which builds four icosahedral shells before the structure goes periodic. Most atoms in it have local icosahedral coordination. Probably the driving force behind the structure found by Shechtman et al. is of this type. We might note that "decagonal snowflakes" seem first to have been reported by Adam and Hogan and coworkers $^{6,7}$ for the corresponding $\mathrm{Al} / \mathrm{Fe}$ alloy, but were then not so fully characterized.

(2) The boron compounds, summarized graphically by Sullenger and Kennard ${ }^{8}$, where many boron compounds, notably $\alpha$ - and $\beta$-boron and $B_{12} C_{3}$, have rhombohedral unit cells with $\alpha$ about $65.5^{\circ}$, closely corresponding to the acute quasiunit-cell of the Penrose pattern. Here the symmetry results from the icosahedral clusters of boron atoms produced by the directed bonding requirements of boron to which Bcrezin ${ }^{9}$ has drawn attention. It might be noted that in $\beta$-boron the packing is hierarchic, 12 icosahedra being themselves packed icosahedrally around a thirteenth.

(3) Tetrahedrally connected networks, where dodecahedral cages can also appear because of the closeness of the tetrahedral angle of $109.47^{\circ}$ to the vertex angles of a pentagon $\left(108^{\circ}\right)$. These occur in clathrasils (cage silicates) and in clathrate hydrates.

Using the structural elements which occur in the zeolite ZSM-39 ${ }^{10}$ and in the type I gas hydrate ${ }^{11}$ we have constructed hypothetical unit cells which would correspond to those required for the Penrose pattern. The acute unit cell is composed of Si-O polyhedra as in the ZSM-39 sheets and these polyhedra are the duals of those in the $\beta$-boron structure. The unit cell edges consist of alternating dodecahedra sharing faces (two per edge, so that the cell edge length is 4.45408 times the edge length of the dodecahedron). The corresponding obtuse cell consists of the same faces (arranged with $\alpha=116.57^{\circ}$ instead of its supplement) but has, at its centre, a polyhedral cage of 18 faces with two dodecahedral caps (of six pentagons each) and a belt of six hexagons equatorially.

Next to this cage the dodecahedra are dislocated and have each two hexagonal and two square faces as well as eight pentagonal faces. Thus, the Penrose pattern reported for alloys might also occur in silicates or hydrates, the dodecahedra of the open tetrahedral structure being dual to the icosahedra of the close-packed metallic structures.

The same two acute and obtuse units may also be assembled in various crystalline ways with, for example, the ratio of 5 acute to 3 obtuse. In view of the occurrence of the two kinds of unit cells in the numerical ratio $\tau$ in the Penrose pattern, it might be timely to look back at the electron compounds of Hume-Rotheray ${ }^{12,13}$, some of which are locally icosahedral, whose electron/atom ratios are $21 / 13$ (these often with an atomic ratio of $8 / 5$ as for $\mathrm{Cu}_{5} \mathrm{Zn}_{8}$ and $3 / 2$ for $\mathrm{CuZn}$ which might seem to be convergents to the golden number (and also 7/4 which is not), to see where else the Fibonacci series may be detected.

Department of Crystallography,

Birkbeck College (University of London), Malet Street,

London WC1E 7 HX

1. Shechtman, D. G., Blech, I, Gratias, D. \& Cahn, J. W Phys. Rev. Lett. 53, 1951-1953 (1984)

2. Maddox, J.. Nature, 313, 263, (1985)

3. Mackay, A. L. Sov. Phys. Crystallogr. 26, $517-522$ (1981); Physica 114A, 609-613 (1982)

4. Frank, F. C. Proc. R. Soc. 215A, 43-46 (1952).

5. Bergman, G., Waugh. J. L. T. \& Pauling. L. Acta Crystullogr $10,254(1952)$

6. Moore, W. J. Physical Chemistry 5th Edn, 265 (1972).

7. Kobayashi, K. \& Hogan. L. M. Phit. Mag. 40A, $399-407$ (1979).

8. Sullenger, D. R., Kennard, C. H. L. Scient. Am. 96-107 (July 1966)

9. Berezin, A A. Nature, 314, 500 (1985).

10. Schlenker, J. L. et al. Nature 294, 340-342 (1981).

11. Pauling, L. \& Marsh, R. E. Proc. natn. Acad. Sci. U.S.A: $38,112-118(1952)$

12. Hurne-Rotheray, W. J. Inst. Metals 35, 295 (1926).

13. Pauling. L. The Nature of the Chemical Bond 3rd Edn, 429 (Cornell University Press. Ithaca, 1969).

\section{Loess in the Bering Land Bridge}

SIR - In his News and Views article on the Bering Land Bridge, Colinvaux ${ }^{1}$ reported that the yedoma deposits of Siberia long described as alluvium or lacustrine silt - are actually loess, emplaced by wind action when "dry, cold and windswept" conditions prevailed in that part of Siberia. The climatic consequences of this conceptual change are profound and Academician Shilo and co-workers are to be congratulated in bringing about this revolution. Once an idea is in place (for example that a particular deposit is lacustrine silt), it can be very difficult to change; witness the remarkably long time it took to recognize the widespread loess in southern England. But, if the Siberian story is to be fully told there should be a nod of acknowledgement in the direction of Troy Péwé and his proposals that Siberian "silts" were loess" 2,3 . Péwé and Journaux, admittedly working west of the immediate Bering Strait area, showed that loess was widespread in Yakutia and made a good case for the existence of significant Siberian loess deposits ${ }^{4}$.

IAN SMalley

Department of Earth Sciences,

University of Waterloo,

Waterloo, Ontario,

Canada N2L $3 G 1$

1. Colinvaux. P. Nature 314, 581-582 (1985)

Péwé. T.L. Abs. tih Biernial Meeting Amer. Quat. Ass. 47-56 (1976)

Péwé T.L. Journaux. A. \& Stuckenrath, R. Ouat. Res. 8 $51-63(1977)$

Péwe. T.L. \& Joumaux. A U.S Geol Surv. Prof. Pap. 1262 (1983); Luess Letr 10. 22-27 (1983)

\section{Scientific Correspondence}

Scientific Correspondence is intended to provide a forum in which readers may raise points of a rather technical character which are not provoked by articles or letters previously published (where Matters Arising remains appropriate). 